\title{
Protein Fragment
}

National Cancer Institute

\section{Source}

National Cancer Institute. Protein Fragment. NCI Thesaurus. Code C28566.

A fragment of a protein, which may be a diagnostic or prognostic factor and used as a biomarker. $(\mathrm{NCl})$ 